\title{
NEUTRALIZATION OF LEACHATE USING GRAPHITE
}

\author{
Dr. Shanthala B ${ }^{1}$, Mithesh Kumar ${ }^{2}$, Jagadisha ${ }^{3}$ \\ Assistant Professor, Department of Civil Engineering \\ Government Engineering College, Karwar, Karnataka.
}

\begin{abstract}
Landfill leachate are defined as those aqueous streams generated as a consequence of rain water percolation through wastes, biochemical processes in waste's cells and the inherent water content of wastes themselves. The generation of municipal solid waste grows exponentially in urban society as a consequence of population growth, concentration of population in urban centers and new patterns of consumption. One of the main problems generated by this common practice is the production of leachate. It is a very complex wastewater containing different heavy metals, organic and inorganic compounds, some of them refractory and toxic that possesses colour and odour. In the current investigation neutralization of leachate is carried out by electro chemical process using stainless steel as anode and graphite as cathode. Leachate is collected from dumping yard in Karwar and electrochemical process is carried out at different volt, temperature and minutes. The properties of leachate before and after treatment is studied and discussed here.

Key words: Neutralization, Leachate, waste management, Graphite, temperature.
\end{abstract}

\section{INTRODUCTION}

The population growths followed by the urban development have increased fast, so the domestic solid wastes are produced and needs to be managed more frequently. The land filling has been to the main method of the waste management. The current landfill technology is primarily determined by the need to prevent and control leachate problem. Leachate means any liquid percolation through the deposited waste and emitted from or contained within a landfill. The leachate consists of many different organic and inorganic compounds that may be either dissolved or suspended. They will bring potential pollution issues for groundwater and surface waters in nature. The landfill leachate is a secondary contamination related to landfills. At present, leachates from most of landfills were treated by municipal wastewater in municipal wastewater treatment plants (MWTPs).

The management of landfill leachate has become to one of main focus for the environment management of landfill. The leachate normally generated by the rainfall and surface water flow into the landfill, through a period time, they change to the high concentrated wastewater on the bottom of the landfill. Actually, the leachate is a potential threat for the quality of groundwater.

The landfill Leachates contain complex compositions, such as High concentration of ammonia Nitrogen and salt, the suspended solids, N, P and heavy metals, which are belong to the water quality characteristic of leachate also. Various factors could bring the difficult problems for management of landfill leachate.

The method of landfill design consists of several parts related to the control of landfill leachate. However, the special landfill design for leachate control could be divided into three important keys: Pretreatment of landfill solids before the filling into the landfill. Cover system include the daily cover, intermediate cover and final cover. Bottom lines systems include the clay liner, plastic liner, composite liner and leachate collection system. Mass of the leachate treatment methods should through the biological process, physical process or chemical process. In order to saving the management cost, the landfill design could connect with the treatment methods for leachate, such as the nature treatment system - constructed wetland, which through the biological and chemical process to reduce the concentration of leachate. The aim of this work was to survey the present methods of landfill leachate management and find out basic information about the quality and characteristics of landfill leachate. This was done by literature survey about landfill design, leachate management and quality. It also included basic laboratory analyses about landfill leachate collected from a closed landfill site of Karwar dumping yard in Uttara Kannada District, Karnataka. The target of the testing was through the basic laboratory experiment to analyze and realize the characteristic of leachates. In the laboratory analyses total suspended solids (TSS), pH and conductivity of leachate were analyzed.

\section{LITERATURE REVIEW}

Wei Li et al, (2010) reviewed on the application of advanced oxidation processes (AOPs) including ozone-based oxidation, Fenton oxidation, electrochemical oxidation, wet air oxidation, and ultrasound oxidation to treatment of landfill leachate. Among the AOPs reviewed, ozone-based oxidation and electrochemical oxidation are the most frequently studied and widely applied methods for the treatment of landfill leachate. Both techniques can achieve about $15 \sim 95 \%$ of COD removal with COD concentration ranging from 600 to $26,000 \mathrm{mg} / \mathrm{L}$. In particular, electrochemical process can improve $\mathrm{BOD} / \mathrm{COD}$ ratio to close 0.5. Electrochemical process seems to be the best method because the process is technologically simple. From the economic point of view, using electrochemical process as the pretreatment of biological treatment can lower the cost and improve the treatment efficiency

Muhammad Umar et al, (2011) concluded that as a comparison, different optimum dosages were obtained at different locations. Optimum dosage was compared i.e. lower value indicating the lower coagulant requirements and possibly less sludge production. It could be concluded that 
treatment of landfill leachate from different location by coagulation-flocculation process in the presence of $\mathrm{PACl}$ (Polyaluminum Chloride) as a coagulant was effective in the removal of color and COD but poor in case of NH3-N removal. Hence, PACl could be used as an effective pretreatment step for further biological treatment.

Rui Zhao et al, (2012) has concluded that an alternative treatment system that combines the technology of landfill with incineration for waste disposal, through which the recycled landfill gas is transferred to an incinerator as the combustion promoter and heat is used to thermally treat the leachate, in order to reduce the energy consumption and disposal cost. According to the technical possibility analysis, the proposed conceptual model can be designed based on existing technology. Greater benefits could be generated, deriving from the preliminary economic comparison. With the development of technology for landfill gas reutilization and leachate incineration, this conceptual prototype can be realized in the near future, as well as providing a template for leachate and landfill gas control. The economic analysis presented is limited in scope owing to the assumptions made concerning the claimed economic benefits of combining existing technologies, and through the creation of an integrated waste treatment park, designed both to eliminate the difficulties associated with the transport of landfill gas and to reduce the costs of leachate treatment.

D.Norma et al, (2012) has investigated that the application of combined electrochemical techniques, namely electrocoagulation and anodic oxidation, seems feasible for the treatment of leachates from sanitary landfills. In the electrocoagulation analysis, the best specific COD removals per iron or per energy consumptions were obtained at the following experimental conditions: initial $\mathrm{pH}$ of 4 and 8.6, by this order, in the unstirred assays. In general, the use of stirring increases the time needed to start, with a visible rate, the precipitation of the flocs formed in the electrocoagulation. It was observed that the global organic carbon removal does not clearly depend on the electro-coagulation experimental conditions. However, the total COD removal is influenced by the electro-coagulation pretreatment conditions, as well as the average current efficiency, that for the highest applied current density presented better results when the electro-coagulation pretreatment was performed at $\mathrm{pH}$ of 6 .

\section{MATERIALS AND METHODS}

\subsection{Materials}

1. Anode: The anode material employed in the present study was stainless steel with the dimension of $10 \times 5 \mathrm{~cm}$. The effective area of the cathode was $50.0 \mathrm{~cm}^{2}$. The figure 1 represent the sample of anode used in the experiment.

2. Cathode: Graphite was used as cathode with combination. It is a type of silver substrate insoluble cathode (SSIC) classified under dimensionally stable cathode (DSC). The figure 2 represent the sample of cathode used in the experiment.

3. Power Supply: A stabilized DC power supply was used as the source of electric current for the experiment. The current voltage is adjustable between 0-6 Amperes and
0-60 voltage with digital power supply. The figure 3 represents the powerplay used in the experiment.

4. Magnetic Stirrer: Magnetic stirrer was used in experiment for continuous process of stirring. A stir bar is placed within the liquid which provides the stirring action. They are bar shaped and often octagonal in cross-section. Stir bar are typically coated in Teflon. The figure 4 shows magnetic stirrer used in the experiment.

5. Electrochemical Reactor Assembly: The experiment is conducted by batch process. An undivided cell of $500 \mathrm{ml}$ capacity (glass beaker) is used throughout the study. The experimental operators are constructed as depicted in the fig. The anode and cathode were positioned vertically and parallel to each other with an inner electrode gap of $3 \mathrm{~cm}$. This electrode was dipped in electrolyte solution. The copper wire is used for making connection between electrode and D.C power system. The positive terminal is connected to anode and negative to the cathode. The reactor is kept in glass bowl containing water to maintain constant temperature of the electrolytic cell. The solution is constantly stirred with magnetic stirrer in order to maintain uniform concentration of the electrolyte solution. In the first set Stainless steel is used as anode \& Graphite used as cathode. The Leachate is treated for $0^{\circ}$ Temperature \& $20^{\circ}$ Temperature of a voltage of 10 Voltes, 20 Voltes \& 30 Voltes, with a combination of $10,20,30,40,50, \& 60$ minutes. Total we obtain 36 sample with Graphite treatment.

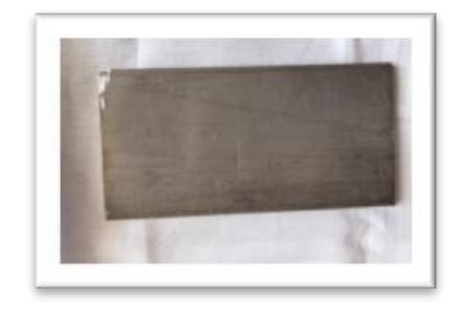

Fig 1: Stainless Steel as Anode

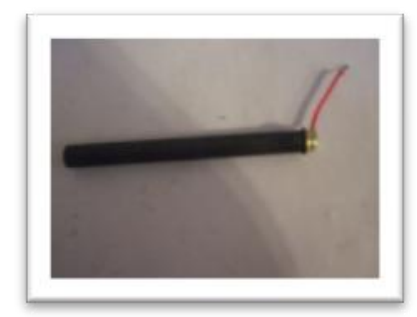

Fig 2: Graphite as Cathode

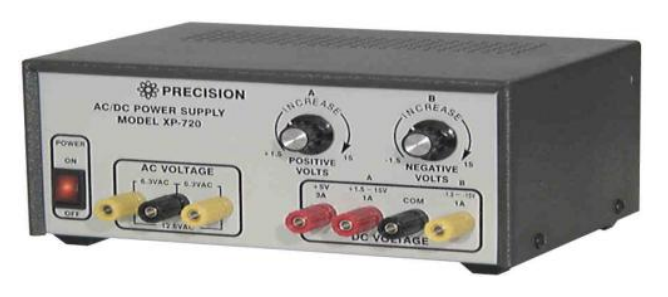

Fig 3: DC Power Supply 


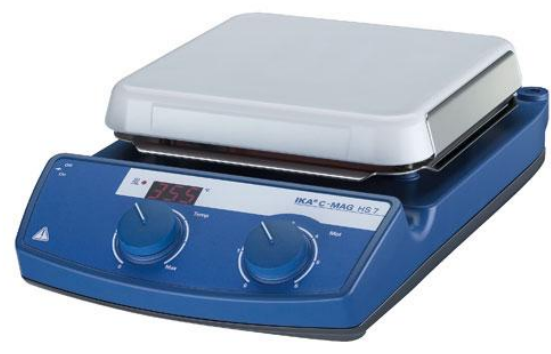

Fig 4: Magnetic Stirrer

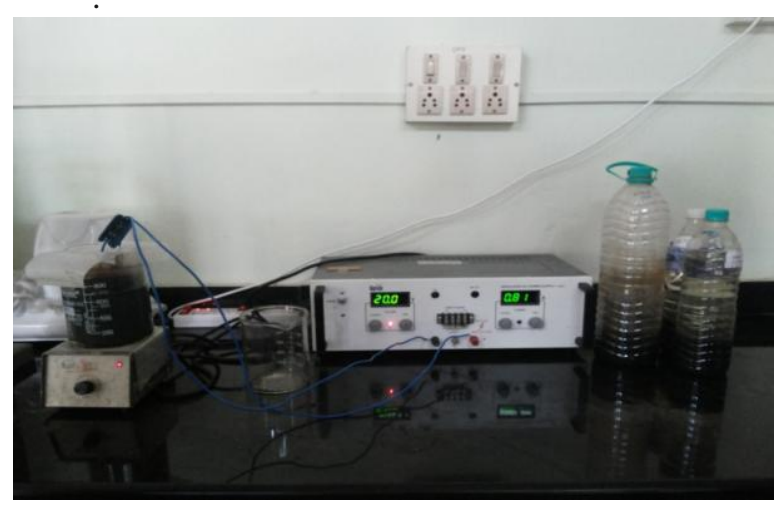

Fig 5: Reactor assembly

\subsection{Methodology}

The working methodology is schematically represented in Fig 6 as follows.

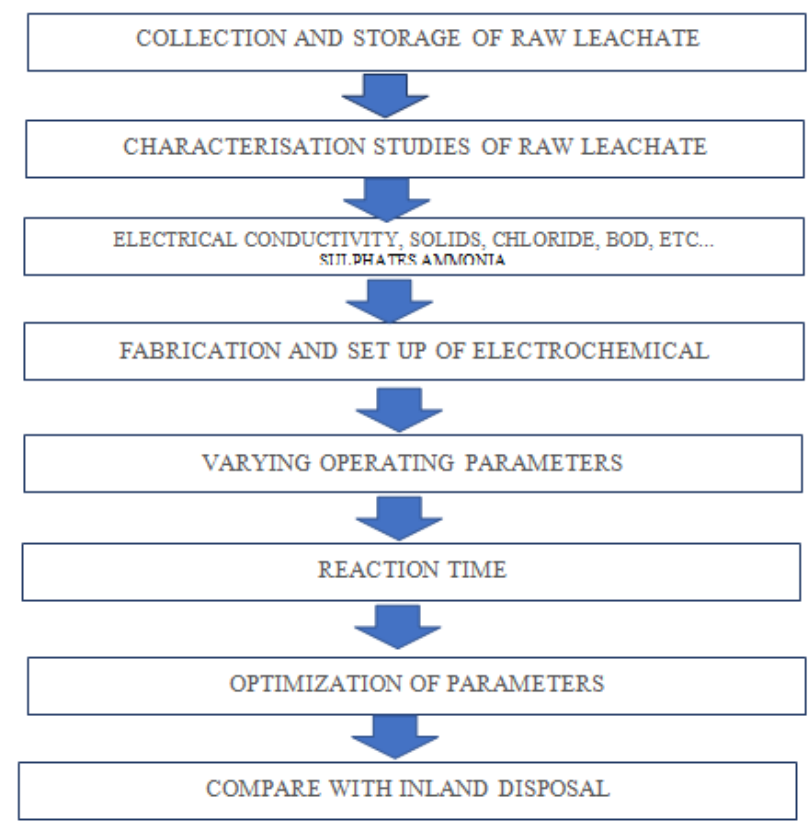

Fig 6: Working Flow Chart

IV. RESULT \& DISCUSSION

4.1 The water quality around dumping site

The results for the water sample collected from the different places nearby dumping sites of Karwar presented in Table 1 . The collected water sample characteristics were found out using standard methods. Almost all the water samples collected was found to be affected due to the leachate action. Table 1: Water Analysis Result of sample neat dumping site

\begin{tabular}{|c|c|c|c|c|c|c|}
\hline \multirow[t]{2}{*}{ SL NO } & \multirow[t]{2}{*}{ CONSTITUENTS } & \multicolumn{4}{|c|}{ KARWAR } & \multirow{2}{*}{$\begin{array}{c}\text { DRINKING } \\
\text { WATER } \\
\text { STANDARDS }\end{array}$} \\
\hline & & $\begin{array}{l}\text { WEL L1 } \\
(\mathrm{mgl})\end{array}$ & \begin{tabular}{|l|}
$\begin{array}{l}\text { WEL L2 } \\
(\mathrm{mgl})\end{array}$ \\
\end{tabular} & $\begin{array}{l}\text { WEL L3 } \\
(\mathrm{mgl})\end{array}$ & $\begin{array}{l}\text { BORE } \\
\text { WELL (mgl) }\end{array}$ & \\
\hline 1 & ACIDITY & 87.5 & 19 & 71.5 & 101 & $<50$ \\
\hline 2 & ALKALINITY & 269 & 118 & 218.5 & 252.5 & $200-600$ \\
\hline 3 & HARDNESS & 200 & 56 & 150 & 155 & $300-600$ \\
\hline 4 & CHLORIDE & 98 & 26.5 & 85 & 85 & 250 \\
\hline 5 & D O & 6.3 & 7.1 & 6.6 & 6.8 & $4-8$ \\
\hline 6 & BOD & 3.9 & 4.1 & 3.8 & 4.3 & $1-2$ \\
\hline 7 & COD & 5.6 & 5.33 & 4.2 & 3.7 & $<50$ \\
\hline 8 & $\mathrm{Ph}$ & 6.72 & 8.65 & 6.91 & 7.1 & $6.5-8.5$ \\
\hline
\end{tabular}

4.2 Raw Sewage Sample

The leachate sample was characterized by $\mathrm{pH}$ of 9.32 , moderate conductivity suitable for electrolysis, with a TDS of $2308 \mathrm{mg} / \mathrm{l}$. The sample also contained significant amount of chloride that contributed to conductivity. The leachate has some free ammonia also. The leachate sample was characterized by $\mathrm{pH}$ of 9.85 . It also contains moderate of $2750 \mu$ s suitable for electrolysis, with TDS of $1399 \mathrm{mg} / \mathrm{l}$. The sample also contained significant amount of chloride that contribute to conductivity. The leachate has some free ammonia also. Iron content were not found which means that it does not contains much industrial wastes. Chemical Oxygen demand was found to be little high about $786 \mathrm{mg} / \mathrm{l}$. Table 6.1 shows results of untreated sample.

Table 2: Test Results of Untreated Samples

\begin{tabular}{|c|c|c|c|c|c|c|c|c|c|}
\hline \multicolumn{2}{|c|}{ SAMPLE } & \multicolumn{2}{|c|}{ ALKALINITY } & \multirow[t]{2}{*}{$\mathrm{pH}$} & \multirow[t]{2}{*}{$\mathrm{NaCl}$} & \multirow[t]{2}{*}{ TDS } & \multirow[t]{2}{*}{$\begin{array}{l}\text { conduct } \\
\text {-jwity }\end{array}$} & \multirow[t]{2}{*}{ BOD } & \multirow[t]{2}{*}{ HARDNESS } \\
\hline VOLTS & MINUTES & $\begin{array}{l}\text { PHENOL } \\
\text {-PHTLEIN }\end{array}$ & METHYL & & & & & & \\
\hline \multirow[t]{6}{*}{10} & 10 & & 480 & 7.40 & 5.40 & 1371 & 2741 & 14.80 & 236 \\
\hline & 20 & & 480 & 7.70 & 5.30 & 1346 & 2694 & 4.00 & 204 \\
\hline & 30 & & 460 & 8.42 & 5.00 & 1293 & 2584 & 1.60 & 152 \\
\hline & 40 & 540 & & 8.21 & 5.00 & 1289 & 2580 & 19.20 & 148 \\
\hline & 50 & 600 & & 8.66 & 4.90 & 1245 & 2499 & 31.60 & 88 \\
\hline & 60 & 640 & & 8.45 & 4.90 & 1258 & 2516 & 48.80 & 144 \\
\hline \multirow[t]{6}{*}{20} & 10 & & 380 & 7.47 & 5.10 & 1316 & 2632 & 12.80 & 232 \\
\hline & 20 & & 280 & 8.43 & 4.90 & 1247 & 2496 & 14.00 & 128 \\
\hline & 30 & & 360 & 7.34 & 5.00 & 1266 & 2541 & 12.40 & 172 \\
\hline & 40 & 80 & & 9.13 & 4.70 & 1212 & 2422 & 33.20 & 40 \\
\hline & 50 & 140 & & 9.14 & 4.70 & 1212 & 2424 & 33.60 & 28 \\
\hline & 60 & 160 & & 9.36 & 4.70 & 1214 & 2424 & 3.60 & 32 \\
\hline \multirow[t]{6}{*}{30} & 10 & & 440 & 8.46 & 5.00 & 1280 & 2544 & 8.80 & 168 \\
\hline & 20 & & 340 & 8.54 & 4.70 & 1201 & 2400 & 10.00 & 128 \\
\hline & 30 & 80 & & 9.03 & 4.70 & 1206 & 2410 & 15.60 & 76 \\
\hline & 40 & 140 & & 9.35 & 4.80 & 1221 & 2444 & 19.60 & 52 \\
\hline & 50 & 120 & & 9.62 & 4.80 & 1217 & 2436 & 5.60 & 28 \\
\hline & 60 & 200 & & 9.88 & 4.70 & 1212 & 2421 & 6.80 & 196 \\
\hline
\end{tabular}

\subsection{Characteristics Of Leachate After Treatment}

The test result of leachate after electrochemical process at different voltage and temperature are presented in Table $3 \&$ 4. The graph at zero and twenty degree temperature w.r.t $\mathrm{pH}$ , NaCl, TDS , BOD are plotted and presented in Fig 
Table 3: Test Result of leachate after treatment at different parameter and Zero-degree temperature.

\begin{tabular}{|l|l|l|l|l|}
\hline SL.NO & Test parameter & Result unit & Sample & Disposal Standards \\
\hline 1 & Ph & & 9.85 & $5.5-9$ \\
\hline 2 & Conductivity & $\mu \mathrm{s}$ & 2750 & 5000 \\
\hline 3 & Total dissolved solids & $\mathrm{mg} / \mathrm{L}$ & 1399 & 2100 \\
\hline 4 & Total solids & $\mathrm{mg} / \mathrm{L}$ & 3376 & 3000 \\
\hline 5 & Volatile solids & $\mathrm{mg} / \mathrm{L}$ & 1456 & 1500 \\
\hline 6 & Iron, as Fe & $\mathrm{mg} / \mathrm{L}$ & N.D & - \\
\hline 7 & Chloride, as CI- & $\mathrm{mg} / \mathrm{L}$ & 589.00 & 1000 \\
\hline 8 & Sulphones SO4 ${ }^{2-}$ & $\mathrm{mg} / \mathrm{L}$ & 20.96 & - \\
\hline 9 & Free ammonia as NH3 & $\mathrm{mg} / \mathrm{L}$ & 85.03 & 50 \\
\hline 10 & Nitrate, as NO ${ }^{-}$ & $\mathrm{mg} / \mathrm{L}$ & 6.20 & - \\
\hline 11 & $\begin{array}{l}\text { Biochemical oxygen demand(5 day@20 } \\
\text { C) }\end{array}$ & $\mathrm{mg} / \mathrm{L}$ & 300.00 & 30 \\
\hline 12 & Chemical oxygen demand & $\mathrm{mg} / \mathrm{L}$ & 786.00 & \\
\hline 13 & Alkalinity (For 100ml Sample) & $\mathrm{mg} / \mathrm{L}$ & 30.2 & \\
\hline 14 & Acidity (for $100 \mathrm{ml}$ Sample) & $\mathrm{mg} / \mathrm{L}$ & 29.0 & \\
\hline 15 & NaCl & $\%$ & 5.2 & \\
\hline
\end{tabular}

Table 4: Test Result of leachate after treatment at different parameter and Twenty-degree temperature

\begin{tabular}{|l|l|l|l|l|l|l|l|l|l|}
\hline \multicolumn{2}{|l|}{ SAMPLE } & \multicolumn{2}{l|}{ ALKALINITY } & $\mathrm{pH}$ & $\mathrm{NaCl}$ & TDS & Conductivity & BOD & HARDNESS \\
\hline VOLTS & MINUTES & $\begin{array}{l}\text { PHENOL } \\
\text {-PHTLEIN }\end{array}$ & METHYL & & & & & & \\
\hline 10 & 10 & & 440 & 8.41 & 5.00 & 1277 & 2553 & 22.00 & 212 \\
\hline & 20 & & 360 & 8.45 & 4.80 & 1231 & 2449 & 2.40 & 120 \\
\hline & 30 & & 400 & 8.48 & 4.80 & 1221 & 2454 & 6.80 & 124 \\
\hline & 40 & & 260 & 8.28 & 5.10 & 1294 & 2590 & 21.20 & 176 \\
\hline & 50 & & 340 & 8.21 & 4.80 & 1250 & 2490 & 6.80 & 112 \\
\hline & 60 & & 160 & 8.19 & 4.90 & 1254 & 2514 & 6.00 & 132 \\
\hline 20 & 10 & & 420 & 8.80 & 4.90 & 1244 & 2488 & 11.60 & 128 \\
\hline & 20 & 140 & & 8.79 & 4.70 & 1203 & 2405 & 11.20 & 68 \\
\hline & 30 & 160 & & 9.26 & 4.60 & 1180 & 2369 & 2.40 & 44 \\
\hline & 40 & 120 & & 9.00 & 4.60 & 1191 & 2386 & 9.20 & 44 \\
\hline & 50 & 120 & & 9.90 & 4.70 & 1207 & 2412 & 29.60 & 40 \\
\hline & 60 & 220 & & 9.22 & 4.70 & 1208 & 2412 & 7.60 & 44 \\
\hline 30 & 10 & & 420 & 7.84 & 4.70 & 1216 & 2434 & 10.80 & 152 \\
\hline & 20 & & 300 & 7.62 & 4.90 & 1007 & 2013 & 15.60 & 132 \\
\hline & 30 & & 380 & 7.23 & 4.90 & 1250 & 2500 & 24.40 & 160 \\
\hline & 40 & & 340 & 7.45 & 4.40 & 1141 & 2273 & 2.80 & 148 \\
\hline & 50 & & 380 & 6.60 & 4.90 & 1243 & 2485 & 1.20 & 210 \\
\hline & 60 & 240 & & 10.22 & 4.90 & 1253 & 2508 & 2.00 & 50 \\
\hline
\end{tabular}

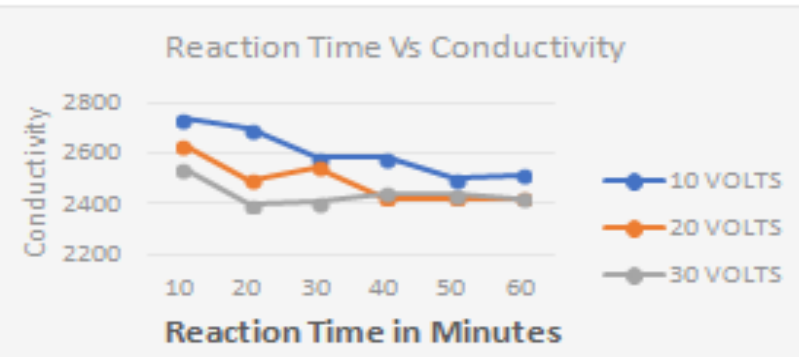

Fig 7: Reaction Time Vs Conductivity at Zero Degree Temperature

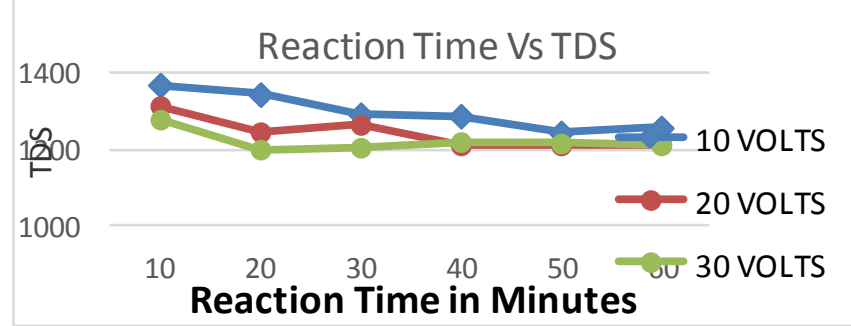

Fig 8: Reaction Time Vs TDS Zero Degree Temperature

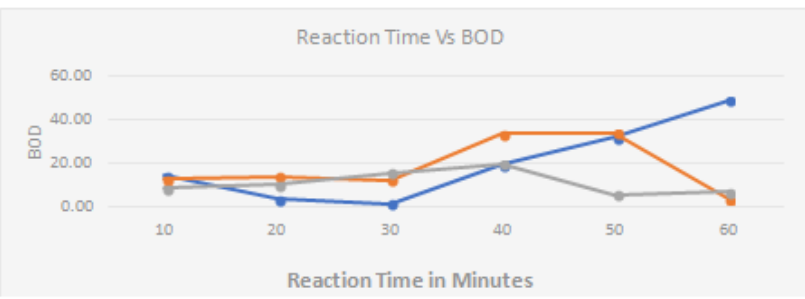

Fig 9: Reaction Time Vs BOD at Zero Degree Temperature

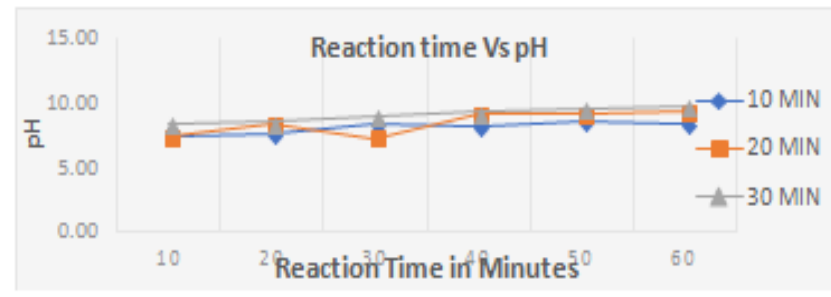

Fig 10: Reaction Time Vs pH at Zero Degree Temperature

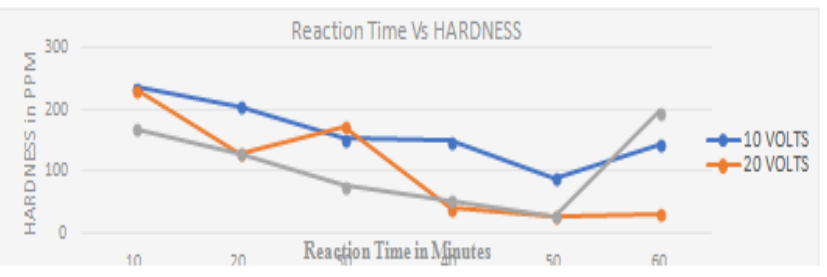

Fig 11: Reaction Time Vs Hardness at Zero Degree Temperature

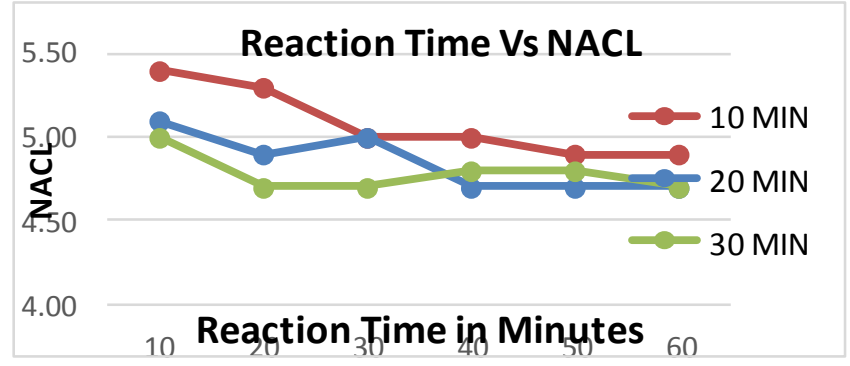

Fig 12: Reaction Time Vs $\mathrm{NaCl}$ at Zero Degree Temperature

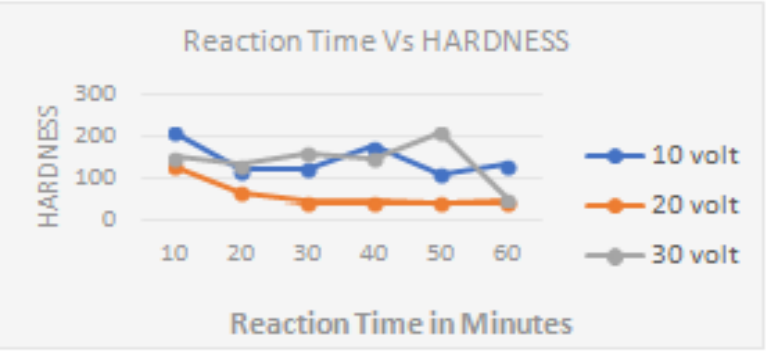

Fig 13: Reaction Time Vs HARDNESS at Twenty Degree Temperature

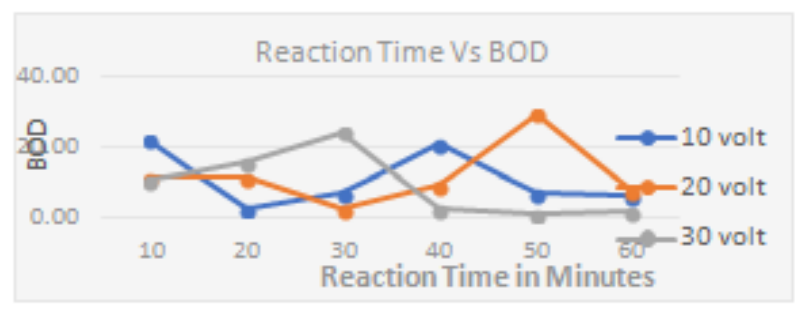

Fig 14: Reaction Time Vs BOD at Twenty Degree 
Temperature

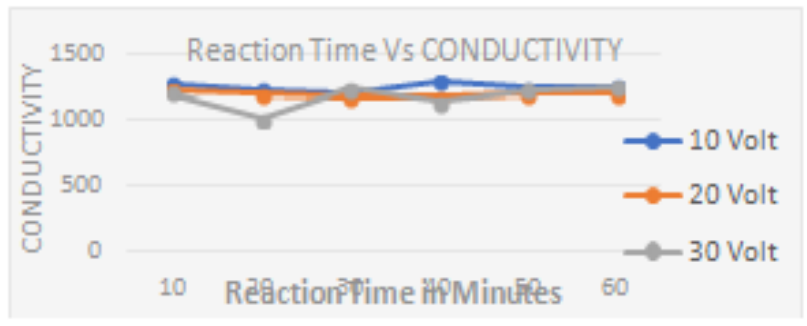

Fig 15: Reaction Time Vs CONDUCTIVITY at Twenty Degree Temperature

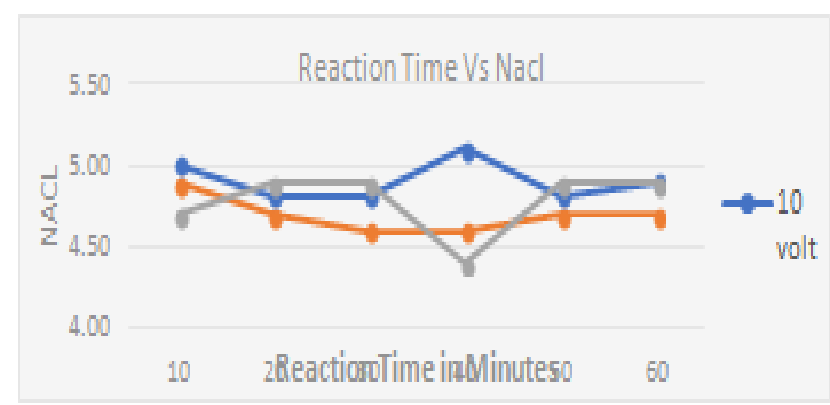

Fig 16: Reaction Time $\mathrm{Vs} \mathrm{NaCl}$ at Twenty Degree Temperature

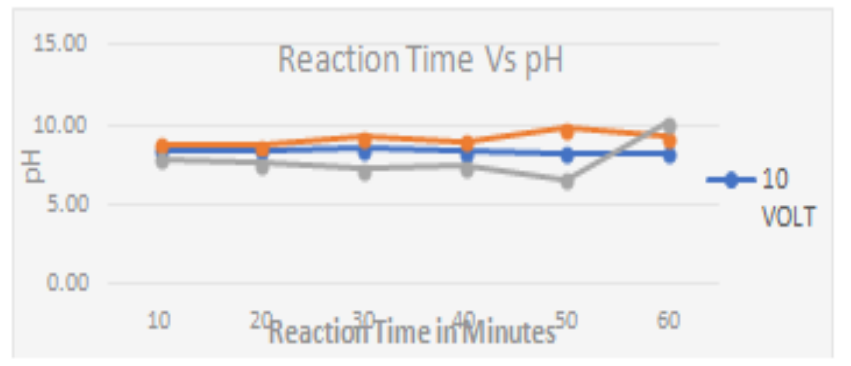

Fig 17: Reaction Time Vs $\mathrm{pH}$ at Twenty Degree Temperature

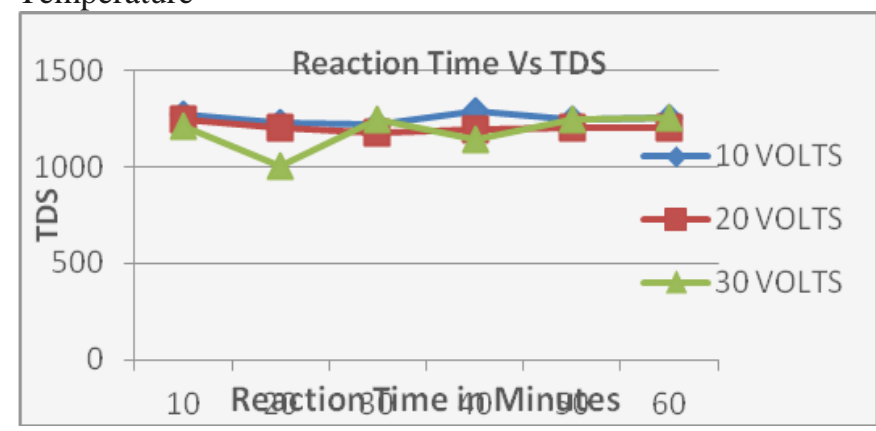

Fig 18: Reaction Time Vs TDS at Twenty Degree Temperature

The graph of reaction time $\mathrm{Vs} \mathrm{pH}$ has been plotted for Graphite. After the treatment with Silver minimum pH of 8.4 is obtained at 10 Volts, 20 minutes. It's also observed that $\mathrm{pH}$ was increase after treatment for 30 Voltage onwards. Significant change in $\mathrm{pH}$ is observed for Graphite treatment and it's reducing up to 7.02 from 9.85 .

Considerable change in $\mathrm{pH}$ is obtained for 20 Voltage and for 30 minutes reaction time. It is also observed that $\mathrm{pH}$ is drastically decries for $10,20, \& 30$ Voltage. It is observed that COD was reduced greater extent of $104 \mathrm{mg} / \mathrm{l}$ in Silver treatment. Which mean that COD does not depend on $\mathrm{pH}$
Values as seen in after treatment method. Its falls was on disposal standards. A drastic reduction in COD is observed in Graphite treatment. The minimum COD of $32 \mathrm{mg} / \mathrm{l}$ was obtained for 30 Volts of 60 minutes reaction time. In Graphite treatment COD falls within the disposal limit. From the graph it's observed that TDS was found to be within the disposal standards in both the case. Its observed that alkalinity and acidity are reduced drastically in both the treatment.

\section{CONCLUSION}

$\mathrm{pH}$ of treated sample in silver was found to be higher than disposal standards where as in Graphite its well below the disposal limits and lowest $\mathrm{pH} 7.02$ was obtained in 20 Volts 30 Minutes.COD of treated sample was reduced to a greater extant from $786 \mathrm{mg} / \mathrm{l}$ to $104 \mathrm{mg} / \mathrm{l}$ in Silver and $32 \mathrm{mg} / \mathrm{l}$ in Graphite Treatment.Conductivity and TDS values were found to be within the limits both before and after treatment.Chloride values were found to be within the limits, before treatment.Acidity value are reduced to greater extend from $29 \mathrm{ml}$ to $0.8 \mathrm{ml}$ for $100 \mathrm{ml}$ sample in both the case.Alkalinity value are reduced to greater extend from 30.2 $\mathrm{ml}$ to $0.8 \mathrm{ml}$ for $100 \mathrm{ml}$ sample in both the case.Iron and oil traces are not found in the sample.It is economical method when compared to other electrochemical oxidation method.In detail analysis will be carried out for BOD to see the impact of electrolysis process. Chloride, Sulphate, ammonium and Nitrate analysis is having to be done. The experiment may be carried out for varying temperature to see impact of temperature on electrolysis process. Analysis can be done for different seasons to analysis leachate characteristics. Investigation can be done on practical implementation.

\section{REFERENCES}

[1] C Ramprasad,'Electrochemical treatment of landfill leachate' Int. Journal of Applied Sciences and Engineering Research', 2012, Vol. 1, No 2.

[2] Raffaello cossu et al, 'Electrochemical Treatment of Landfill Leachate: Oxidation at $\mathrm{Ti} / \mathrm{PbO} 2$ and $\mathrm{Ti} / \mathrm{SnO} 2$ Anodes', environ. Sci. Technol 1988, vol 32,3570-3573.

[3] Andrew Rowley \& Duncan Stratton-Campbell,' The Electrochemical Treatment of Landfill Leachate Leachate,2002.

[4] Cabeza A., Urtiaga A., Rivero M.J. and Ortiz I," Ammonium removal from landfill leachate by anodic oxidation.', 2007, vol 144 (3), 715-719.

[5] Deng Y. and Engelhard J.D.,' Electrochemical oxidation for landfill leachate treatment,' Waste Management, 2007,vol 27,380-388

[6] Amokrane. A., Comel. C and Veron. J., "Landfill Leachate pretreatment by coagulation flocculation', 1997, Water res, 31, pp 27752782 